\title{
Rosa moschata Seed Oil
}

National Cancer Institute

\section{Source}

National Cancer Institute. Rosa moschata Seed Oil. NCI Thesaurus. Code C72204.

The oil pressed from the seed pods of Rosa moschata. Rose hip oil is used as an ing redient in skincare products. 